\title{
Sintering Behavior and Machinability in Mica Glass-Ceramic of the System $\mathrm{SiO}_{2}-\mathrm{Al}_{2} \mathrm{O}_{3}-\mathrm{MgO}-\mathrm{K}_{2} \mathrm{O}-\mathrm{B}_{2} \mathrm{O}_{3}-\mathrm{F}$
}

\author{
E. ERCENK* AND S. YiLmaZ \\ Sakarya University, Engineering Faculty, Department of Metallurgical and Materials Engineering \\ Esentepe Campus, 54187 Sakarya, Turkey
}

\begin{abstract}
Mica glass-ceramic was prepared by sintering method from in the $\mathrm{SiO}_{2}-\mathrm{Al}_{2} \mathrm{O}_{3}-\mathrm{MgO}-\mathrm{K}_{2} \mathrm{O}-\mathrm{B}_{2} \mathrm{O}_{3}-\mathrm{F}_{2}$ system. The sintering behavior and machinability of a glass-ceramic composition were examined. The starting materials were mixed and milled in an alumina ball mill for $2 \mathrm{~h}$. Then the powders were sieved to obtain grain sizes smaller than $75 \mu \mathrm{m}$. For the shaping process, disc samples were prepared by pressing at $100 \mathrm{MPa}$. The pressed discs were sintered at temperatures in the range from 900 to $1200{ }^{\circ} \mathrm{C}$ for $2 \mathrm{~h}$ in an electric furnace using a heating rate of $5{ }^{\circ} \mathrm{C} / \mathrm{min}$. X-ray diffraction analysis, scanning electron microscopy, and machinability tests for characterization were performed on sintered samples. The results showed that all samples exhibited similar phases formation and good machinability.
\end{abstract}

DOI: $10.12693 /$ APhysPolA.125.629

PACS: 61.05.cp, 68.37.Hk, 81.20.Ev, 81.20.Wk, 81.05.Je, 81.05.Mh

\section{Introduction}

Glass-ceramics are normally obtained by a controlled crystallization process of suitable glasses. It can be produced from different waste or natural materials such as fly ash, high furnace slags, or natural volcanic rocks. Initially, glass base structures are transformed to glass-ceramics via controlled crystallization. The composition of the crystalline phases and the crystallite sizes define the properties of the final material. Ceramic base materials are not suitable for some applications due to the brittle properties of the ceramics and glass-ceramics against to mechanical effects as cutting and drilling [1]. Some modifications in chemical composition and production methods can provide better mechanical behavior as for these effects. One of the important materials about the improvement of machinability of the ceramics is mica base glass-ceramics. Mica containing glass-ceramics are used as high-quality electrical insulators and show high resistance to thermal shock and exhibit good machinability [2]. Mica glass-ceramics based on the $\mathrm{SiO}_{2}-\mathrm{MgO}-$ $\mathrm{MgF}_{2}-\mathrm{K}_{2} \mathrm{O}$ system are commercial and these materials exhibit unique properties, such as remarkable cleavage, flexibility, and elasticity, enabling therefore excellent machinability [3]. Commercial mica-type glass-ceramic, of which the main crystal is fluorophlogopite-type mica, also exhibits favorable properties; heat resistance, electrical insulating, and high mechanical strength [4].

In the present study, the effects of varying sintering/ crystallization temperature on the crystal phases, the machinability and the microstructure properties of $\mathrm{SiO}_{2}-$ $\mathrm{Al}_{2} \mathrm{O}_{3}-\mathrm{MgO}-\mathrm{K}_{2} \mathrm{O}-\mathrm{B}_{2} \mathrm{O}_{3}-\mathrm{F}_{2}$ system were investigated. It had been made to achieve mica glass-ceramics with maximum density and desirable machinability through

*corresponding author; e-mail: ercenk@sakarya.edu.tr the addition of $\mathrm{B}_{2} \mathrm{O}_{3}$ and $\mathrm{Al}_{2} \mathrm{O}_{3}$ to the base composition.

\section{Experimental procedure}

The chemical composition of the samples used in this work was $48 \% \mathrm{SiO}_{2}, 18 \% \mathrm{Al}_{2} \mathrm{O}_{3}, 15 \% \mathrm{MgO}, 10 \% \mathrm{~K}_{2} \mathrm{O}$, $5 \% \mathrm{~B}_{2} \mathrm{O}_{3}$, and $4 \% \mathrm{~F}$ by weight. The raw materials such as $\mathrm{SiO}_{2}, \mathrm{AlF}_{3}, \mathrm{Al}_{2} \mathrm{O}_{3}, \mathrm{~K}_{2} \mathrm{CO}_{3}, \mathrm{MgCO}_{3}$, and $\mathrm{B}_{2} \mathrm{O}_{3}$ were first ground and mixed by using a alumina ball mill for $2 \mathrm{~h}$. The mixtures were sieved to a particle size fraction of $-75+45 \mu \mathrm{m}$ and then uniaxial pressing was employed to shape the samples. Cylindrical samples (Ø $25 \mathrm{~mm}$ ) were shaped under the $100 \mathrm{MPa}$ load and then sintered at several temperatures between 900 and $1200^{\circ} \mathrm{C}$ the heating rate of $5^{\circ} / \mathrm{min}$ for $2 \mathrm{~h}$. For the crystalline phases observation, X-ray diffraction (XRD) analysis (Rigaku D/MAX, $\mathrm{Cu} K_{\alpha}$ radiation) was used. The microstructural examinations by using scanning electron microscopy (SEM) (JEOL 6060) were performed at polished and etched surfaces, the solution of $5 \mathrm{vol} \% \mathrm{HF}$ for 1-2 min was used for etching process. Energy-dispersive spectrometer attachment (EDS) was employed for elemental analysis. Furthermore, machinability tests were applied to the disc shaped specimens using $5 \mathrm{~mm}$ diamond drills with $200 \mathrm{rpm}$ drilling rate under uncontrolled load.

\section{Experimental results}

The XRD patterns of the samples sintered at temperatures in the range from 900 to $1200{ }^{\circ} \mathrm{C}$ are seen in Fig. 1. $\mathrm{MgAl}_{2} \mathrm{O}_{4}$ [spinel (ASTM card no: 01-082-2424)], $\mathrm{SiO}_{2}$ [quartz (ASTM card no: 01-070-3755)], $\mathrm{KMg}_{3}\left(\mathrm{Si}_{3} \mathrm{Al}\right) \mathrm{O}_{10} \mathrm{~F}_{2}$ [fluorphlogopite (ASTM card no: 00-016-0344)] and $\mathrm{MgAl}_{2} \mathrm{O}_{4}$ [magnesium dialuminium oxide (ASTM card no: 01-077-1193)] phases were determined by XRD in all samples. Especially, the phase called fluorphlogopite $\left(\mathrm{KMg}_{3}\left(\mathrm{Si}_{3} \mathrm{Al}\right) \mathrm{O}_{10} \mathrm{~F}_{2}\right)$ is significant for machinability. Increase in sintering temperature 
caused weak fluorphlogopite peaks formation. This phase was observed in the XRD patterns of the samples sintered at 900 and $1000{ }^{\circ} \mathrm{C}$; strongly, over the $1000^{\circ} \mathrm{C}$, not only these peaks but also all peak intensities decreased depending on temperature. Spinel $\left(\mathrm{MgAl}_{2} \mathrm{O}_{4}\right)$, quartz, fluorphlogopite and magnesium dialuminium oxide phases overlapped with the high intensity lines. Machinable glass-ceramic as commercial trademark MACOR consists of fluorphlogopite mica in a borosilicate glass matrix. The XRD results are in good agreement with the literature [5]. It was probable that the crystallization temperatures were around $900-1000^{\circ} \mathrm{C}$ and the increase in temperatures caused melting of the crystalline phases.

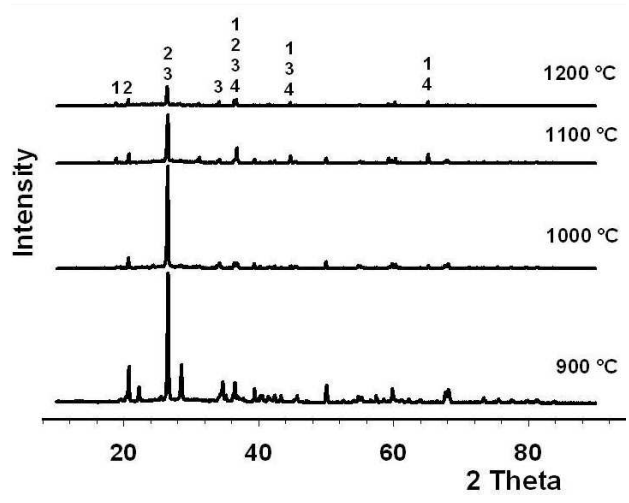

Fig. 1. XRD patterns of the samples depending on sintering temperature $(1-$ spinel, $2-$ quartz, 3 - fluorphlogopite, 4 - magnesium dialuminium oxide).

Table exhibits detected crystalline phases and the macro images as to machinability test results. As one can see in Table, machinability test was performed for all samples, successfully. Any mechanical damage such as fracture was not observed during the machinability tests. Fluorphlogopite is a common phase for machinable glass-ceramics. It provides plastic deformation possibility for glass-ceramics in specific scale. Fluorphlogopite mica is not inclined to distortion and can bear big stress, tension, and compression [1-5]. In this study, fluorphlogopite was a major phase in all samples, other than this, magnesium dialuminium oxide, spinel, and quartz phases were detected for all sintering conditions. On the other hand, clinohumite and kalsilite phases were observed in the samples sintered at lower temperature. When the temperature increased to $1100{ }^{\circ} \mathrm{C}$, these phases decomposed and transformed to the other phases.

In literature, kalsilite phases $\left(\mathrm{KAlSiO}_{4}\right)$ can be stable up to $950^{\circ} \mathrm{C}$; above this temperature, it can transform to the other phases in suitable conditions. For instance, kalsilite reacts with sufficient amorphous $\mathrm{SiO}_{2}$, the phase leucite happened when the glass compacts were sintered at $1000^{\circ} \mathrm{C}[6]$. Clinohumite $\left[\mathrm{Mg}_{9}\left(\mathrm{SiO}_{4}\right)_{4}(\mathrm{~F}, \mathrm{OH})_{2}\right]$ also is a silicate mineral belonging to humite group. The humite series of minerals have the general formula $n\left[\mathrm{Mg}_{2} \mathrm{SiO}_{4}\right]\left[\mathrm{Mg}(\mathrm{OH}, \mathrm{F})_{2}\right]$. This group of minerals is classified as follows: norbergite, chondrodite, humite, and
TABLE

The macro images and crystalline phases versus sintering temperature.

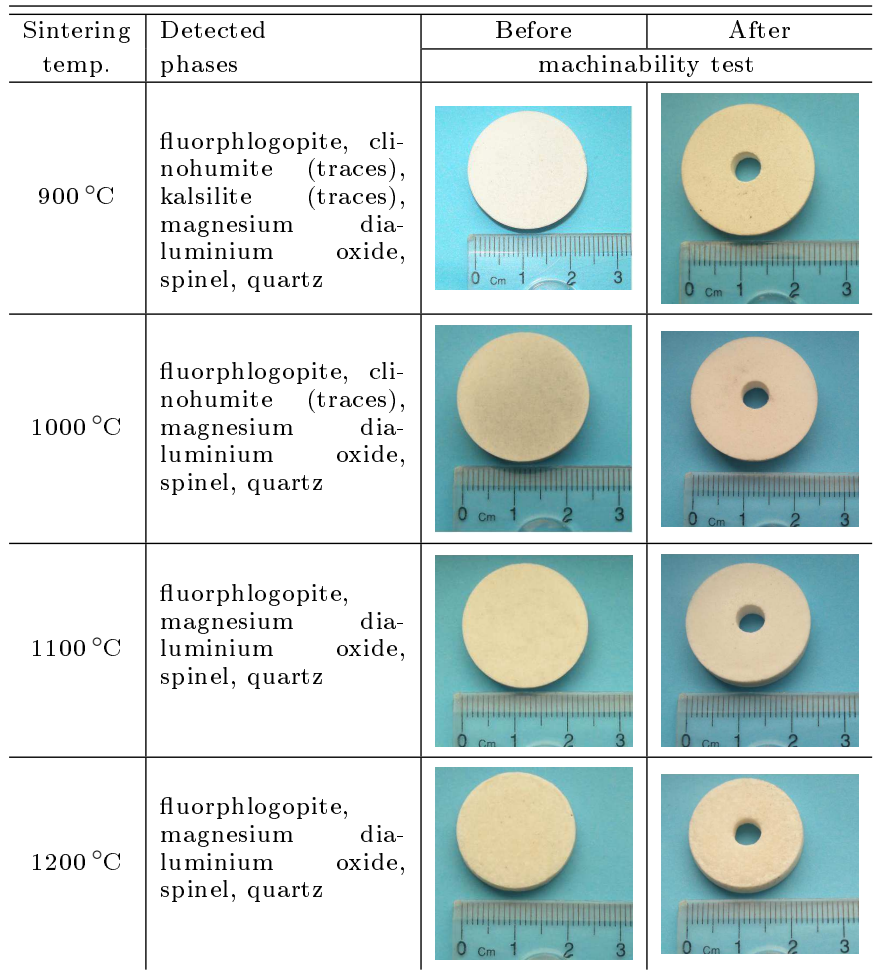

clinohumite [7]. In general, this type of structure is observed in machinable glass-ceramics and presence of these phases can bring about fluorphlogopite formation. That these structures can be unstable at high temperature was presented in the literature [2]. The phase clinohumite decomposed at high temperature in this study. As can be seen in the macro images, firing shrinkage was observed depending on increase in temperature.

Figure 2 shows the SEM images and EDS analysis of the samples sintered at 900 and $1200^{\circ} \mathrm{C}$. The results obtained from EDS analysis deal with the XRD analysis results. For both of the samples sintered at $900^{\circ} \mathrm{C}$ and $1200{ }^{\circ} \mathrm{C}, \mathrm{SiO}_{2}$ rich regions were determined, that can be read as an evidence about the presence of glassy and $\mathrm{SiO}_{2}$ crystalline (quartz) phase in the glass-ceramic. EDS point analysis showed that the potassium elemental peaks were dense in the samples sintered at $900^{\circ} \mathrm{C}$, especially. It was indicated that the regions dominated by fluorphlogopite phase were diffuse in this structure. Apart from the fluorphlogopite, presence of magnesium and aluminium elements pointed that there were magnesium dialuminium oxide and spinel phases in the structure. On the other hand, strong $\mathrm{Mg}, \mathrm{F}, \mathrm{K}$, and $\mathrm{Al}$ peaks in EDS results of this sample showed the formation of the clinohumite and kalsilite phases at $900^{\circ} \mathrm{C}$. It was confirmed by XRD analysis and these phases were decomposed by increase in temperature. Similar situations were detected in the samples sintered at $1200^{\circ} \mathrm{C}$. Fluorphlogopite, magnesium dialuminium oxide, spinel, quartz 
phases were determined in this sample. In the EDS analysis of this sample, clear decreases in $\mathrm{K}$ and $\mathrm{F}$ peak intensities were observed. It can be seen that clinohumite and kalsilite phases decompose and transform to other phases. Marked grains in this microstructure (Fig. 2b) are common images in mica glass-ceramic including fluor, it was presented by Höche et al. as mica plates [8].
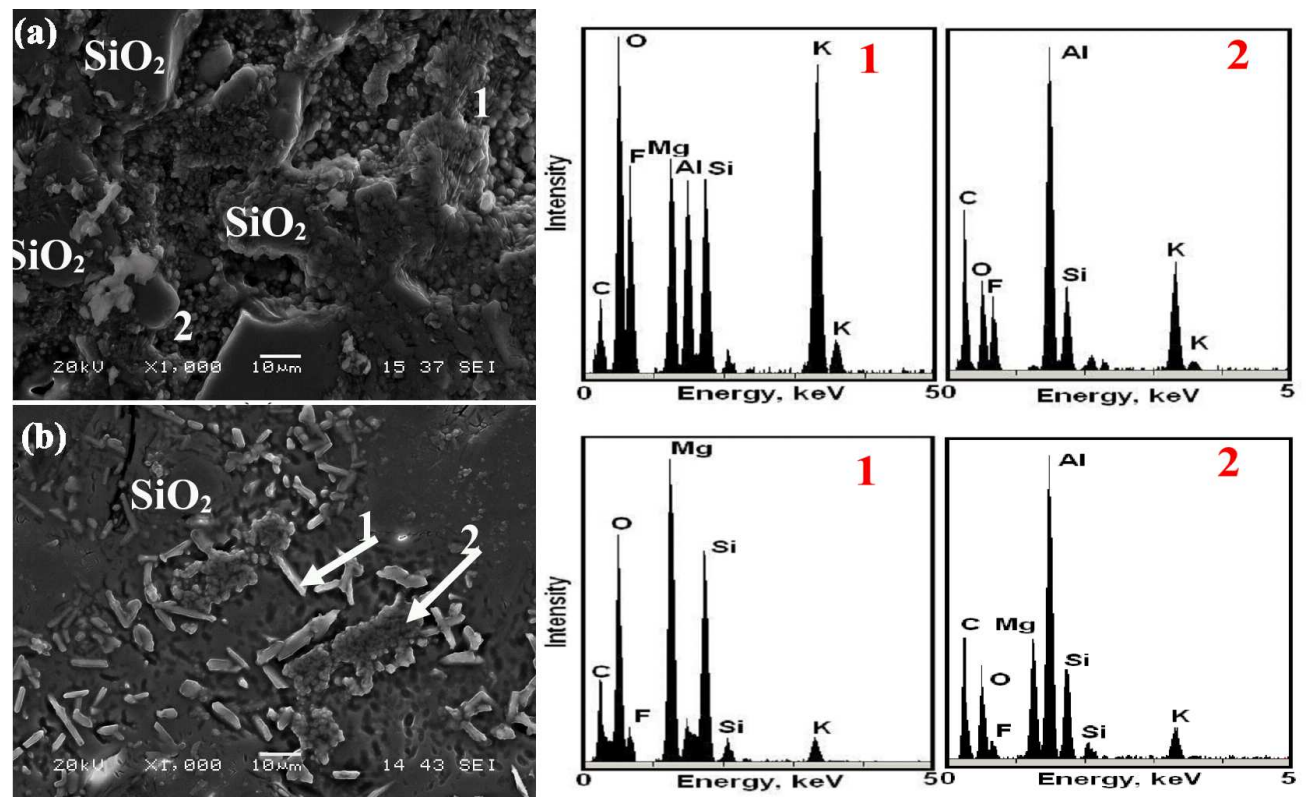

Fig. 2. SEM micrographs and EDS analysis of the samples depending on sintering temperature: (a) $900{ }^{\circ} \mathrm{C}$, (b) $1200^{\circ} \mathrm{C}$.

\section{Summary}

The main object of this study was to produce machinable glass-ceramic materials by a sintering process in $\mathrm{SiO}_{2}-\mathrm{Al}_{2} \mathrm{O}_{3}-\mathrm{MgO}-\mathrm{K}_{2} \mathrm{O}-\mathrm{B}_{2} \mathrm{O}_{3}-\mathrm{F}_{2}$ system. In this study $\mathrm{SiO}_{2}, \mathrm{Al}_{2} \mathrm{O}_{3}, \mathrm{~K}_{2} \mathrm{CO}_{3}, \mathrm{MgCO}_{3}, \mathrm{~B}_{2} \mathrm{O}_{3}$, and $\mathrm{AlF}_{3}$ as fluor source was used. Fluorphlogopite, magnesium dialuminium oxide, spinel, quartz phases were detected in all sintered glass-ceramic sample. Fluorphlogopite is a common phase of this type material, especially. Apart from these phases, clinohumite and kalsilite phases were determined in the diffraction pattern of the samples sintered at $900^{\circ} \mathrm{C}$. These structures were decomposed or transformed due to increase in temperature. To observe machinability performance of the samples, drilling test was performed and it was detected that all samples were drilled without mechanical damage such as crack or fracture.

\section{References}

[1] D.U. Tulyaganov, M.J. Ribeiro, J.A. Labrincha, Ceram. Int. 28, 515 (2002).

[2] A.M. Nassar, E.M.A. Hamzawy, F.M. Hafez, S.S. El Dera, C. Rüssel, Ceram. Int. 38, 1921 (2012).

[3] D.U. Tulyaganov, S. Agathopoulos, H.R. Fernandes, J.M. Ventura, J.M.F. Ferreira, J. Europ. Ceram. Soc. 24, 3521 (2004).

[4] S. Taruta, T. Ichinose, T. Yamaguchi, K. Kitajima, J. Non-Cryst. Solids 352, 5556 (2006).

[5] J. Henry, R.G. Hill, J. Non-Cryst. Solids 319, 13 (2003).

[6] J. Wu, Z. Li, Y. Huang, F. Li, Ceram. Int. 39, 7743 (2013).

[7] S. Lakshmi Reddy, N.C. Gangi Reddy, G. Siva Reddy, B. Jagannatha Reddy, R.L. Frost, Spectrochim. Acta A 65, 684 (2006).

[8] T. Höche, S. Habelitz, I.I. Khodos, J. Cryst. Growth 192, 185 (1998). 